\title{
The association between bubble trails and folia: a morphological and sedimentary indicator of hypogenic speleogenesis by degassing, example from Adaouste Cave (Provence, France)
}

\author{
Philippe Audra ${ }^{1}$, Ludovic Mocochain ${ }^{2}$, Jean-Yves Bigot ${ }^{3}$ and Jean-Claude Nobécourt ${ }^{4}$
}

\begin{abstract}
:
Audra Ph., Mocochain L., Bigot J.-Y. and Nobécourt J.-C. 2009. The association between bubble trails and folia: a morphological and sedimentary indicator of hypogenic speleogenesis by degassing, example from Adaouste Cave (Provence, France). International Journal of Speleology, 38 (2), 93-102. Bologna (Italy). ISSN 0392-6672.

Bubble trails are subaqueous features in carbonate caves, which are made by the corrosion of ascending carbon dioxide bubbles. Folia are calcite deposits resembling inverted rimstone dams in saturated pools. Based on morphological studies in Adaouste Cave (Provence, France) and on studies elsewhere in the world, we propose a new genetic model for folia, close to the model of Green (1991). The association of bubble trails and folia, occurring on overhanging walls, is interpreted to be an indicator of hypogenic degassing occurring just below the water table. The association is the result of juxtaposed processes composed of corrosion along bubble trails and calcite deposition in calcite-saturated pools.
\end{abstract}

Keywords: Bubble trails, folia, carbonic degassing, hypogenic speleogenesis, Adaouste Cave

Received 10 September ;2008 Revised 31 October 2008; Accepted 14 December 2008

\section{INTRODUCTION}

Bubble trails are small channels developed subaqueously in the walls of carbonate caves by corrosion by carbon dioxide bubbles. Folia are among the most curious and rarest calcite speleothems: these subaqueous calcite coatings cover overhanging walls and resemble inverted rimstone dams. Their origin is still debated and several hypotheses have been suggested, among which two main hypotheses are: deposits at the surface of water bodies (pools with oscillating water level) or subaqueous speleothems in thermal caves. In the Adaouste Cave, bubble trails and folia are intimately associated, which is a paradox involving both corrosion and deposition, respectively. This paper presents a detailed analysis of their morphology and spatial distribution that provides a better understanding of their origin and significance.

Our observations of bubble trails and folia from

1. Polytech'Nice-Sophia, Engineering School of Nice - Sophia Antipolis University, 1645 route des Lucioles, 06410 BIOT, FRANCE (Philippe.Audra@unice.fr)

2. Aix-Marseille Université, CEREGE, Europôle de l'Arbois, BP 80, 13545 Aix-en-Provence, Cedex 4, FRANCE \& Centre de Sédimentologie - Paléontologie "Géologie des systèmes carbonatés ", 13331 Marseille, Cedex 03, FRANCE

3. French Association of Karstology (catherine.arnoux@clubinternet.fr)

4. French Association of Karstology (jcnobecourt@free.fr)
Adaouste Cave (Provence, France), and comparison with other occurrences worldwide, allow us to ascribe them to a hypogenic origin by degassing. Moreover, the association between bubble trails and folia provides us with an indicator for hypogenic processes by carbon dioxide degassing that is highly useful for the interpretation of inactive hypogenic caves.

\section{PREVIOUS GENETICAL THEORIES}

Bubble trails have been only recently identified (Chiesi \& Forti, 1987). The discovery of folia occurred earlier (Emerson, 1952), but the understanding of their genesis is still a debate.

\section{Bubble trails (sometimes also designed as bubble- flow canals)}

Bubble trails are smooth and regular solution channels cut in overhanging walls. The cross-section is roughly half-circular, with diameters of 0.5 to 10 $\mathrm{cm}$, ranging from a shallow print (Fig. 1C) to a deep channel (Fig. 1D). The course is essentially straight, with some gentle curves following the steepest slope (Fig. 1A). They were first identified in the caves of the Iglesiente metallic district in Sardinia (Chiesi \& Forti, 1987). They are also mentioned in some sulfuric acid caves, such as the Frasassi Caves in Italy (Galdenzi \& Sarbu, 2000). In Hungary, they were first identified in the cave Ferenc-hegy barlang, and later in the Buda Hills caves, other karst massifs (Bükk, Pilis), and close to the Balaton Lake in Tapolca barlang (Szabó, 


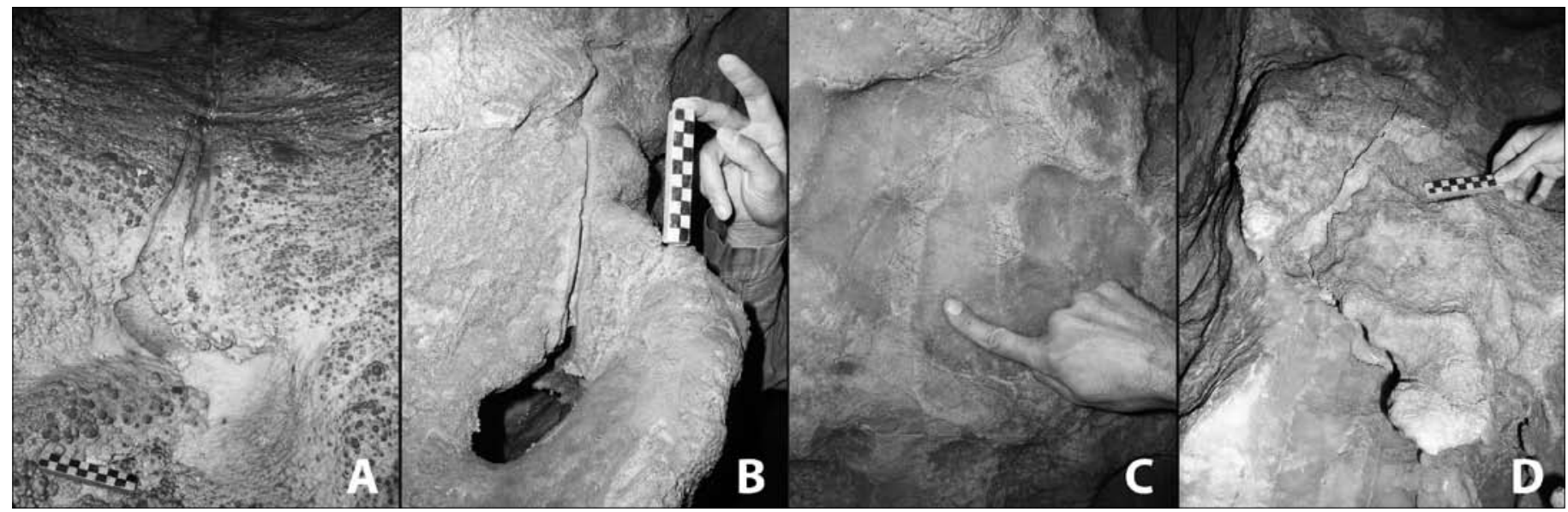

Fig. 1. Bubble trails in Adaouste Cave. Corrosion is limited to the channel, whereas the rest of the wall is covered with a subaqueous calcite coating. A and D: views from below; B and C: front views (photos. J.-Y. Bigot, http://catherine.arnoux.club.fr/photo/13/adao/adao.htm)

2005). Their development is due to carbon dioxide degassing (Chiesi \& Forti, 1987). In the Santa Barbara 2 Cave, the degassing is due to the oxidation of sulfur ore deposits (De Waele \& Forti, 2006). At depth, carbon dioxide remains dissolved because of the high pressure. During the rise of water in the phreatic zone, water degasses $\mathrm{CO}_{2}$ as the depth decreases, typically $15-30 \mathrm{~m}$ depth at the maximum (Luiszer, 1997). Bubbles converge into the steepest upward courses along overhanging walls. The carbon dioxide bubbles locally enhance the solutional aggressivity of the adjacent water. Bubble trails are produced by the continued corrosion along these unchanging routes. Such corrosion features are probably more frequent than suggested by the sparse sites mentioned above. Theoretically, it should be present in most hypogenic caves where carbon dioxide degassing occurs. On the contrary, it does not seem to exist in any other type of cave. It should not be confused with other types of wall and ceiling channels such as paragenetic wall channels, convective channels in deep-seated caves (Klimchouk, 2007), hydrothermal condensationcorrosion channels (Audra, 2007), etc.

\section{Folia (Hill \& Forti, 1997)}

Folia are speleothems resembling inverted rimstone dams or mushroom caps. They occur as undulating ribbons, stacked like leaves, and hence their name (Fig. 2). They grow downward as a continuous coating, exclusively on overhanging walls. The lower rim is horizontal or gently tilted about several degrees. Individual ribbons are in average of $1 \mathrm{~cm}$ thick, less than $10 \mathrm{~cm}$ wide, and separated vertically by empty spaces up to $5 \mathrm{~cm}$. In places they are influenced by currents and are arranged parallel to the flow direction (e.g., in Indian Burial Cave, Nevada; Green, 1991). At the micro-scale, the calcite is deposited in a dendritic microcrystalline fabric. Eventually, this porous dendritic texture is overgrown by large columnar crystals, up to $10 \mathrm{~mm}$ (Kolesar \& Riggs, 2004). Such dendrites and skeleton crystals are the result of a rapid growth and a limited supply of material. For carbonate solutions, this is often caused by the pressure fluctuations associated with mechanical degassing, e.g. the growth tips of stalactites (Maltsev,
1999). Folia are located below the water table, down to several meters or dozens of meters deep. More rarely they mark an oscillating water table, as a horizontal ring that covers the walls, within a vertical range of several centimeters to decimeters (as in Hurricane Crawl Cave, California; and Devil's Hole, Nevada).

Folia are frequently associated with subaqueous speleothems originating from calcite deposition in supersaturated pools, such as cave clouds, calcite rafts, tower cones, and coral towers. All of these deposits are generally, but not systematically, induced by hypogenic degassing producing oversaturation in the pools. Folia were first identified in Indian Burial Cave, Nevada (Emerson, 1952). Currently, they are recorded in fewer than 25 caves worldwide, some active, some inactive (Table 1). Many of these sites are in thermal caves. However, hydrothermal conditions do not seem to control the presence of folia: the temperature of water and the temperature of calcite crystallization deduced from fluid inclusions range across a large spectrum (from 20 to $120^{\circ} \mathrm{C}$ ), and Hurricane Crawl is a cold epigenic cave.

Two main hypotheses have been proposed for the origin of folia:

1/ The oscillation of a saturated pool surface (Davis 1997). At the surface of supersaturated pools, precipitation is due to evaporation (Halliday, 1954a; Davis, 1973; Jennings, 1982). Precipitation can be due to strong degassing, trapped gas is involved in shaping the folia growth around bubbles, and water-level oscillations are essential to explain upper and lower limits of the folia (Davis 1997). Calcite precipitation occurs either directly by particle accretion, or by accretion of calcite rafts. Hill (1987) specifies that after the lowering of the water, the sloping folia edges developed like draperies, where calcite botryoids ("popcorn") may grow. Kolesar \& Riggs (2004) correlate folia with the water oscillation due to earth-tidal waves, which would favor calcite precipitation by degassing and subsequent saturation of the capillary film during the lowering of the water.

2/ Phreatic degassing in thermal water (Green, 1991, 1997): the $\mathrm{CO}_{2}$ bubbles originating from degassing are trapped below wall irregularities. These small gas pockets focus the precipitation of 

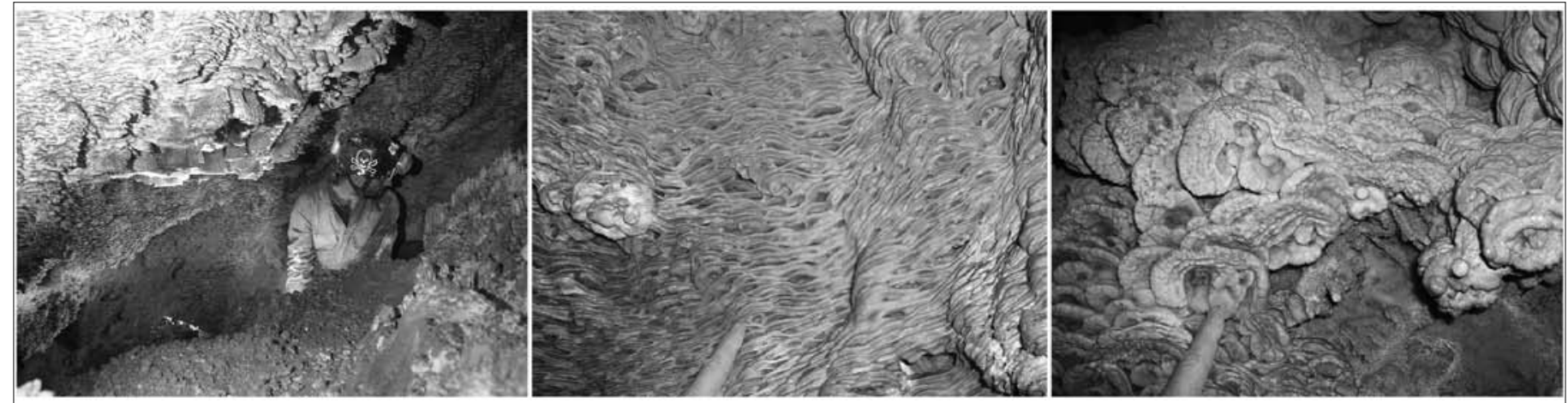

Fig. 2. Folia in Adaouste Cave. Left: folia occur exclusively below overhanging walls; center: front view toward the top showing the "inverted rimstone" morphology; right: view from below showing the outward and downward development as inverted cups (photos. J.-Y. Bigot, http:// catherine.arnoux.club.fr/photo/13/adao/adao.htm)

Table 1 - Folia occurrences, about 25 sites worldwide

\begin{tabular}{|c|c|c|c|c|c|c|}
\hline Cave & Location & $\begin{array}{l}\text { Active I } \\
\text { fossil }\end{array}$ & Hydrothermalism & $\begin{array}{c}\mathrm{CO}_{2} \\
\text { degassing }\end{array}$ & Tectonic / hydrogeology & Reference \\
\hline Indian Burial Cave & USA, Nevada & $\mathrm{F}$ & $\begin{array}{l}\text { 86-119 }{ }^{\circ} \mathrm{C}\left(\mathrm{T}_{H} \text { of the fluid }\right. \\
\text { inclusions) }\end{array}$ & & & $\begin{array}{c}\text { Emerson, } 1952 \\
\text { Green, } 1991 \text { Halliday, } 1957\end{array}$ \\
\hline Hurricane Crawl Cave & USA, California & A & $\stackrel{\text { (river cave) }}{\text { No }}$ & $\begin{array}{c}\text { From } \\
\text { upwelling } \\
\text { phreatic }\end{array}$ & & Davis, 1997 \\
\hline Crystal Sequoia Cave & USA, California & & & & & Davis, 1997 \\
\hline Goshute Cave & USA, Nevada & $\mathrm{F}$ & & & & Halliday, 1954b \\
\hline Devil's Hole & USA, Nevada & A & Water table $34^{\circ} \mathrm{C}$ & $x$ & $\begin{array}{l}\text { Non karstic active } \\
\text { extensional fault }\end{array}$ & Kolesar \& Riggs, 2004 \\
\hline Gneiss Cave & USA, Utah & $\mathrm{F}$ & & & $\begin{array}{l}\text { Calcite folia coating onto a } \\
\text { gneiss wall }\end{array}$ & Green, 1997 \\
\hline Bida Cave & USA, Arizona & & & & & $\begin{array}{l}\text { Davis, } 1965 \\
\text { Hill, } 1982\end{array}$ \\
\hline Groaning Cave & USA, Colorado & & & & & Davis, 1973 \\
\hline Agua Caliente Cave & USA, Arizona & A & Cave at $38^{\circ} \mathrm{C}$ & & & McLean, 1965 \\
\hline Carlsbad Cave & USA, New-Mexico & $\mathrm{F}$ & Carlsbad $20-25^{\circ} \mathrm{C}$ & & Basin margin & Davis, 1970 \\
\hline Lechuguilla Cave & USA, New-Mexico & $\mathrm{F}$ & Carlsbad $20-25^{\circ} \mathrm{C}$ & & Basin margin & $\begin{array}{l}\text { Davis, } 2000 \\
\text { Hose, } 1992\end{array}$ \\
\hline $\begin{array}{c}\text { Cinco Cuevas (caverna } \\
\text { de las) }\end{array}$ & Cuba & & & & & Nuñez-Jimenez, 1975 \\
\hline $\begin{array}{l}\text { Pulpo } \\
\text { (sima del) }\end{array}$ & Spain, Murcia & A & Water table $21^{\circ} \mathrm{C}$ & & & Ferrer Rico, 2004 \\
\hline Benis (sima de) & Spain, Murcia & A & Water table $21^{\circ} \mathrm{C}$ & & & Ferrer Rico, 2004 \\
\hline $\begin{array}{c}\text { Ermite } \\
\text { (grotte de l') }\end{array}$ & France, Pyrénées & A & $\begin{array}{l}\text { Water table } 19{ }^{\circ} \mathrm{C} \\
\text { Thermal sulfidic spring } 38^{\circ} \mathrm{C}\end{array}$ & $\mathrm{x}$ & $\begin{array}{l}\text { Artesian flow path in deep } \\
\text { syncline }\end{array}$ & Bigot \& Nobecourt, unpub. \\
\hline Adaouste (grotte de l') & France, Provence & A & $\begin{array}{l}\text { Abandoned at } 11 \mathrm{Ma} \\
\text { Thermal springs along Durance } \\
\text { fault }\end{array}$ & $\mathrm{x}$ & $\begin{array}{l}\text { Durance active } \\
\text { transcurrent fault }\end{array}$ & Audra et al., 2002 \\
\hline $\begin{array}{c}\text { Pál-Völgy - Matyas-Hegy } \\
\text { barlang }\end{array}$ & Hungary, Buda Hills & $\mathrm{F}$ & Springs $20-27^{\circ} \mathrm{C}$ & & Rim of the Danube rift & Takacsné Bolner, 2005 \\
\hline Jószef-hegy barlang & Hungary, Buda Hills & $\mathrm{F}$ & Springs $20-27^{\circ} \mathrm{C}$ & & Rim of the Danube rift & Takacsné Bolner, 2005 \\
\hline Molnar-Janos & Hungary, Buda Hills & A & Water table $20-27^{\circ} \mathrm{C}$ & $\mathrm{x}$ & Rim of the Danube rift & Takacsné Bolner, 1993 \\
\hline Matyas-Farras & Hungary & & & & & Takacsné Bolner, 1993 \\
\hline Giusti (grotta) & Italy, Tuscany & A & Thermal spring $34^{\circ} \mathrm{C}$ & $\mathrm{x}$ & & $\begin{array}{l}\text { Forti \& Utili, } 1984 \\
\text { Piccini, } 2000\end{array}$ \\
\hline Ryan Imperial Cave & Australia, Queensland & & & & & Jennings, 1982 \\
\hline Cupp-Coutunn Cave & Turkmenistan & $\mathrm{F}$ & $\begin{array}{l}80-170^{\circ} \mathrm{C}\left(\mathrm{T}_{H} \text { of the fluid }\right. \\
\text { inclusions, from fluorite and } \\
\text { calcite) }\end{array}$ & & Basin margin & $\begin{array}{c}\text { Maltsev, } 1997 \\
\text { Maltsev \& Self, } 1993\end{array}$ \\
\hline
\end{tabular}


calcite around the bubbles with downward-orientated growth. Successive upward "sloughing" produces the structure of inverted rimstones. Thermal rising flow concentrates the deposition below overhanging walls.

Regarding these hypotheses and observations as a whole, Hill \& Forti (1997) do not distinguish the variety of physical settings (e.g., in perched pools, water table, or shallow depth in the phreatic zone) and come to no single explanation for folia genesis. However, they admit a close relationship with the water table and with subaqueous speleothems such as cave clouds, as well as with pool speleothems such as rafts.

\section{NEW EVIDENCE IN THE ADAOUSTE CAVE}

The Adaouste cave opens below the top of the Mirabeau anticline. This fold is cut by the Durance water gap, along an active transcurrent fault, lined by thermo-mineral springs (Audra et al., 2002). Hypogenic flow tends to converge toward the highest places of buried aquifers, where discharge can occur. Consequently, the outflow is located at the intersection between the anticline hinge and the water gap, which acted as regional base level. The Adaouste Cave was probably active in the Tortonian (11 Ma), at the beginning of the Durance water gap entrenchment. The main entrenchment phase of the water gap occurred in the Messinian (Clauzon, 1979). The cave drained, became perched, and consequently has been preserved from any further reworking. Fluid inclusion $\mathrm{TH}$, even if not reliable, tends to shows a trend of temperatures of crystallization higher than cold meteoric environment (Audra \& Häuselmann, 2004). Some ore deposits in the neighborhood (Fe$\mathrm{Mn})$ are associated with hypogenic karst and have preserved microbial evidence in metallic pool fingers (Audra \& Hofmann, 2004). The cave is made of two steep passages following the anticline dip, which rise from about $200 \mathrm{~m}$ depth (Fig. 3). These steep passages connect to the horizontal upper levels $(-18$ and -27) which record past water-table elevations (Audra et al., 2002). These horizontal levels display intense condensation-corrosion features, suggesting the presence of a nearby thermal body (Audra et al., 2007). Below the water table, corrosion concentrated in bubble trails. At depth, carbon dioxide gas was trapped in blind bells with a high pressure, giving rise to hyper-corrosive atmospheres, where condensationcorrosion produced boxworks at the ceiling, as well as drip holes (Fig. 4). Simultaneously, degassing led to supersaturation and massive calcite deposition, as various morphologies: botryoids (popcorn) above the water table; and rafts, tower cones, folia, and coral tower, beneath the water table (Audra et al., 2002). The water/gas interfaces are very clear, showing transition between atmospheric corrosion and subaqueous precipitation (Fig. 5)

\section{Folia and bubble trails in Penitents Chamber}

Observations have been made in Penitents Chamber $(-124 \mathrm{~m})$, together within the main passage above the chamber (Fig. 4). The diversity of subaqueous corrosion and deposition features in this area allow us establishing some relationships, particularly between bubble trails and folia. The bubble trails are converging upward and can reach several meters long before connecting to blind bells (Fig. 1A) or disappearing where the overhanging walls become vertical. No deposits are present in the bubble trails. When a calcite coating occurs on neighboring walls, it is cut by the bubble trails (Fig. 1C).

Folia are developing continuously between -80 and $-120 \mathrm{~m}$ (Fig. 3). In the upper part, they are uniformly corroded and partly covered with subaerial popcorn. In the lower part, folia are not corroded. A standing water level is visible in the Penitents Chamber, around $-110 \mathrm{~m}$. The size of folia increases upward in sequences several meters high. From these observations, we can deduce that:

After their deposition, the highest folia (-80 to $-95 \mathrm{~m}$ ) have been exposed to air by a watertable lowering, then they have been corroded by condensation-corrosion;

The influence of condensation-corrosion is intense in the upper horizontal levels, it decreases downwards, and seems to be absent below $-95 \mathrm{~m}$.

The lowest folia ( -95 to $-120 \mathrm{~m}$ ) have been deposited either simultaneously with the upper ones, with a vertical range of about $30 \mathrm{~m}$, or subsequently as the result of a water-table lowering;

There is no evidence of any subsequent watertable rising, since popcorn covering folia is not covered with any new subaqueous calcite;

The upward increase of folia size reflects the upward increase of gas volume, both by the degassing and by the addition of rising bubbles.

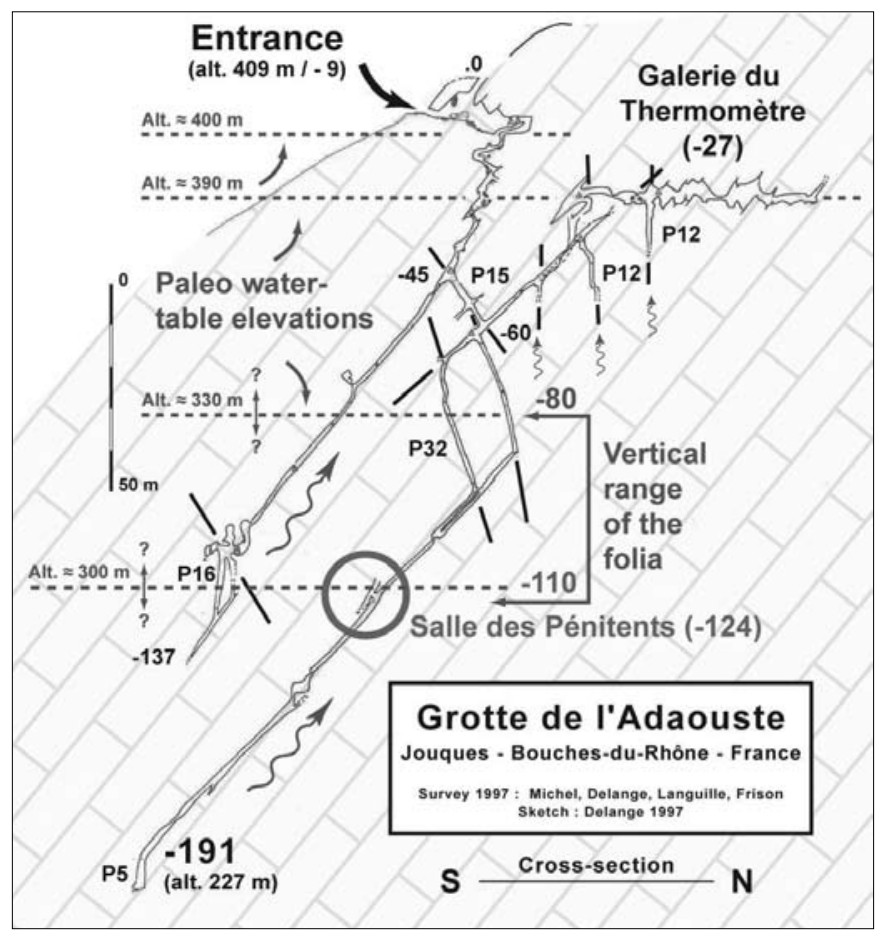

Fig. 3. Adaouste Cave survey. Hypogenic flow (undulated arrows) welled up through conduits along dip and through fissures (black lines); horizontal levels record past water table positions 


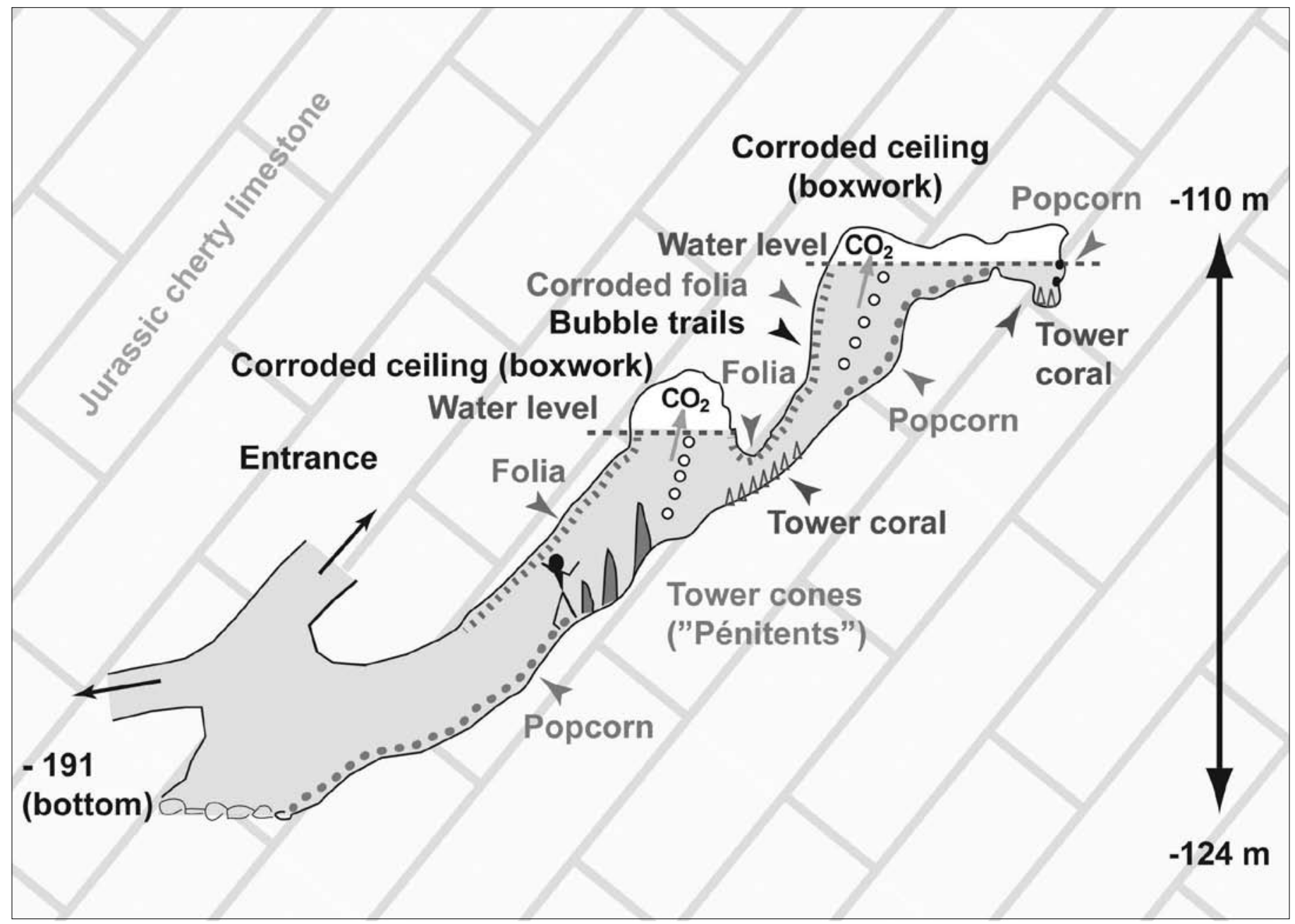

Fig. 4. The Penitents Chamber, an ancient blind phreatic conduit where the cupolas were filled with $\mathrm{CO}_{2}$ from degassing. Distribution of features originating from atmospheric corrosion and subaqueous calcite deposition

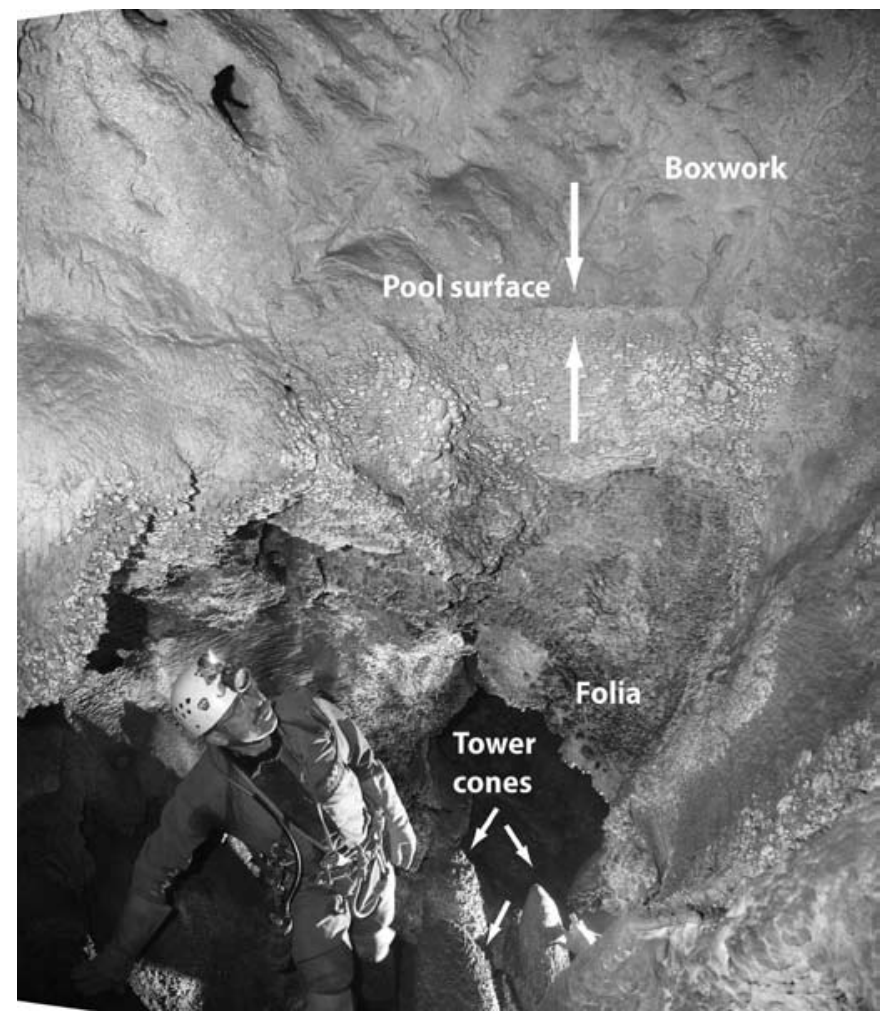

Fig. 5. Interface between a carbon dioxide-rich gas pocket with walls corroded as boxwork (top) and subaquaeous calcite deposits below: folia below overhanging walls, tower cones below the caver (photo. J.-Y. Bigot)

\section{Folia bubbles}

We observed several calcite bubbles inside the folia hollows. We call these speleothems folia bubbles. They are composed of calcite that forms at the waterair contacts of bubbles, by centripetal growth. The development of such features needs the presence of a solution shifting to oversaturation at the waterbubble interface. We suggest the following origin (Fig. 6):

A film of condensation water appears at the vaulted solid top of the bubble, due to the thermal gradient between the thermal water and the rocky ceiling. The gradient is maintained by thermal flux through the rock;

In the high- $\mathrm{CO}_{2}$ atmosphere of the bubble, condensation water becomes hyper-aggressive;

The corrosive water dissolves the calcite and flows along the wall. This migration makes the solution progressively saturated;

At the base of the bubble, evaporation leads to supersaturation;

The calcite precipitates on the lower edge of the folia. The precipitation zone propagates along the bubble, at the water-bubble interface. Since this process involving calcite redistribution inside the cavity seems to be limited, calcite particle accretion from the degassing water-body may also participate to the building of the calcite bubble. 


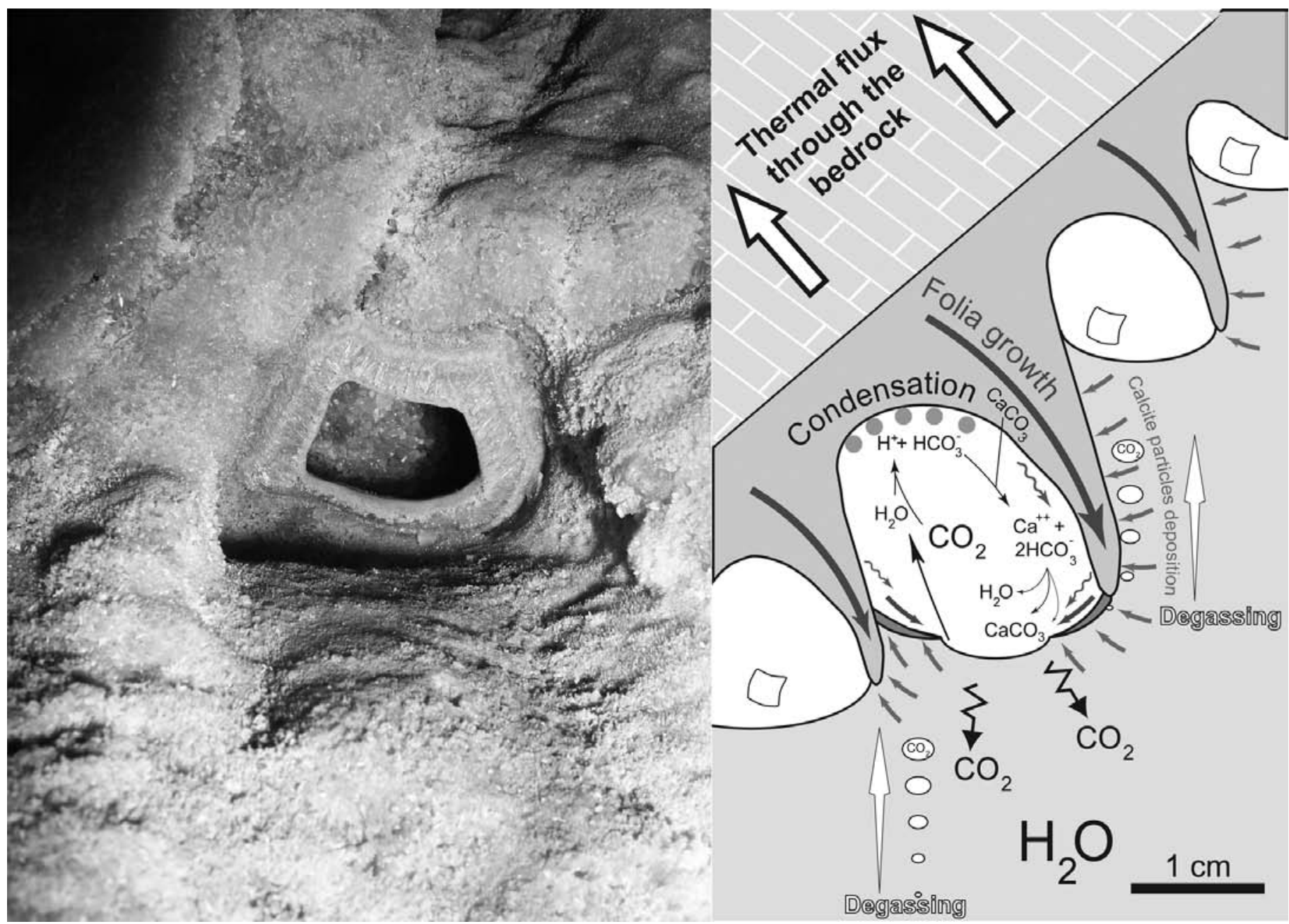

Fig. 6. Left: folia bubble (photo. J.-Y. Bigot). The aperture is about $4 \mathrm{~cm}$ wide. Right: folia and folia bubble development by condensation-corrosion at the top of the carbon dioxide bubble and then by calcite deposition through evaporation at the base of the bubble, at the interface between gas and saturated water. The calcite closing the bubble is shown in dark grey. White arrows show $\mathrm{CO}_{2}$ degassing; small grey arrows show subaqueous calcite particle accretion; long Dark grey arrows show the growing direction of the folia.

\section{DISCUSSION: FOLIA GENESIS AND ASSOCIATION WITH BUBBLE TRAILS, A RECORD OF THERMAL WATER-TABLE DYNAMICS}

\section{Rebuttal to the previous hypotheses \\ Oscillation of a saturated pool surface (Davis 1997).}

The main argument supporting this hypothese is that the constant upper boundary of the deposit is a record of the slow rise and fall of the water body. During these oscillations, accretion of solid material grows downward to enlarge the speleothem. Trapping of bubbles when the water rises, or from degassing, would accentuate this process. However, we identify numerous arguments negating this hypothesis:

The oscillation of a saturated pool is not sufficient by itself to form folia, because such a condition is present in all karst beneath a vegetal cover, and yet folia are on the contrary extremely rare.

The systematic distribution of folia below overhanging walls excludes a simple mechanism of an oscillating pool, which would have similar consequences on non-overhanging surfaces.
Except for their upper limit, folia never display horizontal patterns which would have record some lower water surface.

Regarding the calcite texture, a random texture would be expected from the accretion of particles or rafts; on the contrary, a dendritic texture is observed deriving from the mechanical effect of degassing (Maltsev, 1999).

The particular morphology of inverted rimstone is never clearly explained.

\section{Phreatic degassing in thermal water (Green, 1991, 1997).}

Following this author, calcite particles appear after degassing due to sudden pressure reduction when the fluid expands from a small orifice; the thermal buoyancy raises the particles and accretion occurs around gas bubbles that are trapped below irregularities of the overhanging walls. This hypothesis is consistent with our observations on the whole; however some statements do not seem to be relevant:

Folia are frequently associated to thermalism, but not systematically (Table 1).

Decompression at constrictions sufficient to cause bubbling by cavitation is not feasible 
because cavitation requires flow velocities far above those reasonably possible at all observed sites.

\section{New perspectives for the genesis of folia}

Since previous hypotheses are not or only partly relevant, respectively, we propose a new process to explain the genesis of folia, partly based on Green (1991, 1997) hypothesis:

Below the water table at shallow depth, $\mathrm{CO}_{2}$ degassing produces bubbles rising toward the surface;

The bubbles are trapped beneath irregularities in the overhanging walls, and when the spaces are filled the bubbles slough upward into the next hollow; We effectively observed such underwater process in grotta Giusti (Tuscany, Italy) (Piccini, 2000).

Degassing makes the solution supersaturated, which produces ubiquitous calcite precipitation, except in hollows filled with bubbles. Calcite protrudes outward and downward from wall projections to form the lower edges of the folia. By positive feedback, the size of each trapped bubble increases, and so on.

The folia bubbles clearly show crystallization at the gas-water interface. Consequently, the genesis of folia in subaqueous conditions, due to hypogenic degassing, is demonstrated here. Trapping of bubbles is admitted by both Green and Davis, as the main consequence for degassing, or as a secondary factor occurring when water rises, respectively. We demonstrate that the trapping of bubbles from a strong degassing is essential to obtain the typical hollow morphology of inverted rimstones. Their size increases upward by addition of rising bubbles. Consequently, we think that folia are almost exclusively associated with degassing from hypogenic origin. Only two extremely rare cases mimicking the hypogenic environments were identified in non-hypogenic setting: (1) Hurricane Crawl Cave, where degassing into saturated pools is due to the inflow of epigenic water originating from a mountain karst with dense vegetation; (2) cuevas de Bellamar - El Jarrito, Cuba (Hall, 2008), where the air is mechanically trapped by tidal fluctuations.

The thermalism does not seem to be a necessity, even if frequent. Rising hypogenic flow looks more adequate to explain both the folia morphology and the degassing.

We also demonstrate that folia develop by degassing at shallow depth below the water table, no deeper than about $30 \mathrm{~m}$ (Luiszer, 1997). Sudden degassing deeper in the phreatic zone by decompression at the outlet of constriction is unlikely. The water table acts as the upper boundary, the lower boundary corresponds to the lower limit of degassing. Both boundaries determine the vertical range of the folia deposits. In these conditions, a water-table oscillation (such as in Devil's Hole) is not necessary; it is only occasionally present. The small vertical range of folia in Hurricane Crawl Cave could correspond to some sediment filling which may since have been removed. Regarding the maximum vertical range of the folia, few data are available. They reach about
$40 \mathrm{~m}$ in Lechuguilla Cave, and $30 \mathrm{~m}$ at Adaouste. Such a depth is compatible with the depth of degassing, and also with the amount of water-table lowering that is documented in Adaouste.

\section{The association between bubble trails and folia}

Many bubble trails emerge from folia or cupolas where carbon dioxide has been concentrated (Fig. 7, 1A). The juxtaposition of both features, with a sharp transition lacking any overlap (in the stratigraphic sense), shows that they are coeval. Moreover, their association shows they originate from a common process, i.e. carbon dioxide degassing. Their association is controlled by the wall geometry: if an overhanging wall is absent, the bubbles rise vertically in the water: neither folia nor bubble trails develop; below a convex overhanging wall, the bubbles pour from folia into folia while diverging; below a concave overhanging wall, the bubbles converge toward an invariable trajectory, and a bubble trail gradually appears in the wall; the bubble trail could reach a cupola, from which another bubble trail emerges.

\section{Record of paleo-water tables}

In the Adaouste Cave, the vertical range of the folia, their corrosion in the upper part, and their absence below -120 , allows us to reconstruct the lowering of the thermal water table (Fig. 3). It demonstrates:

The presence of a thermal water table at about -80 $\mathrm{m}$, at the boundary between popcorn corrosion above and of folia deposition below;

The lowering of the water table to the top of the Penitents Chamber $(\approx-110 \mathrm{~m})$. This lowering caused the smoothing by condensation-corrosion of the overlying folia and the development of the underlying folia.

The folia records the recession of thermal activity in the Adaouste Cave.

\section{Non-carbonate features and restriction of the folia term}

Some features resembling folia are made of minerals other than calcite:

In clay: Cave of the Wind and Orient Mine Cave, Colorado (Davis, 1982, 1997), Vass Imbre barlang (Maucha, 1993), and Matyas-Farras, Hungary (Takacsné Bolner, 1993). However, their morphology differs significantly: rims do not overlap and do not form individual inverted cusps. Since they are much too soft to be generated by oscillating water, these clay rims are apparently produced by the regular lowering of a turbid water body (Green, 1997);

In halite: Liquid Crystal Cave, Israel. Initially published as folia (Frumkin, 1997). Actually they correspond to rimstone shelves (Frumkin, pers. comm.).

In sulfur: cueva de Villa Luz (Hose et al., 2000). Soft sulfur "moonmilk" forms inverted and overlaid cusps. However, their bottoms are flat and do not show the specific hollow bases present in calcite folia.

Despite the visual similarities of these features in noncarbonate material, they are not related to the process of bubble trapping. The genetic process is not physico- 


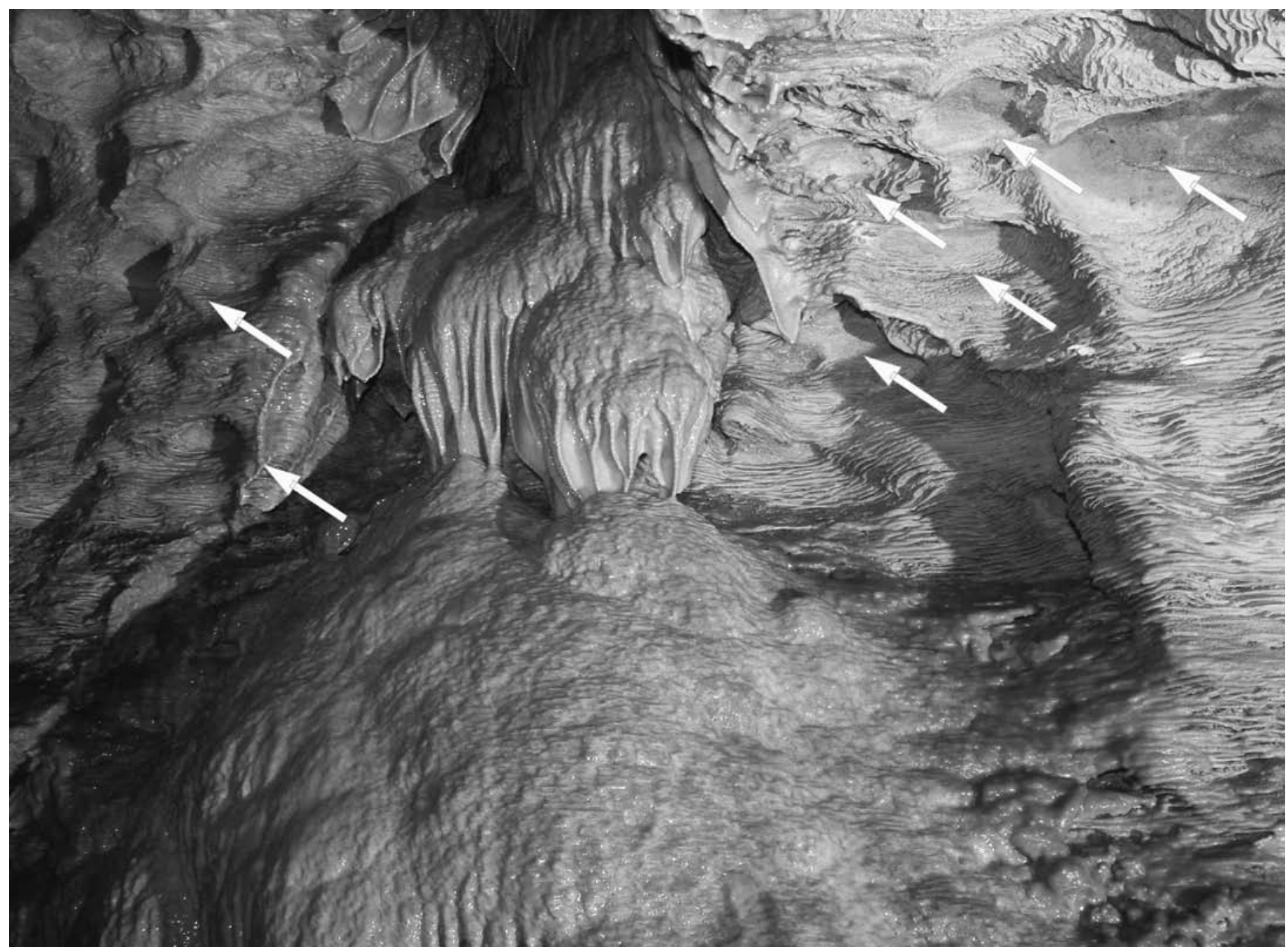

Fig. 7. Folia in Pál-Völgy barlang, Hungary. Arrows indicate cupolas where gas bubbles are trapped and where intense corrosion showing bare rock is clearly visible, whereas walls are covered with a thick folia coating. The flowstone in the center developed after draining (photo. A. Kiss, with permission)

chemical, it rather involves mechanical processes, by the transport of solid particles (in phreatic conditions by lowering of levels of turbid water, or by thin sheets of runoff over walls). Their morphology, roughly as horizontal ribs, with flat bottom in the case of sulfur folia, do not display holes capable of trapping bubbles. Their genetic process, although still largely unknown, is hardly similar to that of folia. Consequently, we think that true folia are exclusively made of calcite; we suggest restricting "folia" to a precise descriptive term for downward-concave calcitic features, and by extension to a genetic term, since these features are associated with a given process. Similar features that owe their existence to different genetic process should have different names, to avoid confusion.

\section{CONCLUSION}

Folia clearly seem to be connected to hypogenic flow. Hydrothermal conditions are typical, however do not seem necessary, as long as a strong carbon dioxide degassing is present. The original hydrothermal hypothesis was initially proposed at a time when hypogenic caves were mainly considered hydrothermal, which is only one aspect of hypogenic speleogenesis, neither systematic nor a principal feature (Klimchouk, 2007).

Folia cover large areas and have unambiguous morphology. Consequently, their occurrence seems to be almost exclusively correlated to a carbonic acid, hypogenic context, involving degassing at shallow depth below the water table. Similar features that occur in non-hypogenic context (e.g., in halite or clay) are clearly different, from both a morphological and a genetic point of view. Their inclusion in the term "folia" should be abandoned.

The appearance of folia results from the following combination: (1) strong (hypogenic) degassing below the water table making bubbles and leading to supersaturation; (2) overhanging walls; (3) trapping of carbon dioxide bubbles, making calcite precipitate at the periphery of bubbles, in a downward growth. If the overhanging wall geometry is dihedral, then there is an association between folia and bubble trails. Folia, and moreover the association between folia and bubble trails, can be considered a very reliable record of hypogenic conditions.

The hypothesis of an oscillating supersaturated water pool must be abandoned. First, because folia formed in this way should be widespread, when in fact they are extremely rare. Moreover, this hypothesis does not give a global explanation for the specific morphology of folia, such as inverted rims.

Since degassing occurs at shallow depth below the water table, folia and bubble trails can also be considered 
a precise record of the water-table position, located at the top of the folia zone.

\section{ACKNOWLEDGEMENTS}

For documentation: P. Delange, J. Despain, D. Green, W. Halliday, P. Kolesar, A. Osborne, and L. Piccini. For field discussion: J. De Waele and S. Galdenzi. For the reviewing and thorough suggestions: B. Lismonde, A. Palmer, C. Self, and Y. Dublyansky.

\section{REFERENCES}

Audra P., 2007 - Karst et spéléogenèse épigènes, hypogènes, recherches appliquées et valorization [Epigene and hypogene karst and speleogenesis. Operative research and valorisation]. Hab. thesis, University of Nice Sophia-Antipolis, 278 p.

Audra P. \& Häuselmann Ph., 2004 - Hydrothermal origin of two hypogenic karst caves in French Provence: Preliminary results from fluid inclusions. Actes des Journées européennes de l'AFK, Le karst de la craie en Normandie, Rouen 2003: 32-34.

Audra P. \& Hofmann B. A., 2004 - Les cavités hypogènes associées aux dépôts de sulfures métalliques (MVT) [Hypogenic cave systems related to metallic sulphide deposits (MVT)]. Le Grotte d'Italia, 5: 35-56.

Audra P., Bigot J.-Y. \& Mocochain L., 2002 - Hypogenic caves in Provence (France). Specific features and sediments. Acta Carsologica, 31 (3): 33-50.

Audra P., Hobléa F., Bigot J.-Y. \& Nobécourt J.-Cl., 2007 - The role of condensation-corrosion in thermal speleogenesis. Study of a hypogenic sulfidic cave in Aixles-Bains, France. Acta Carsologica, 37 (2): 185-194.

Chiesi M. \& Forti P., 1987 - Studio morfologico di due nuove cavità carsiche dell'Iglesiente (Sardegna Sud occidentale) [Morphological study of two new karst caves from Iglesiente (SW Sardinia)]. Ipoantropo, 4: 40-45.

Clauzon G., 1979 - Le canyon messinien de la Durance (Provence, Fr.) : une preuve paléogéographique du bassin profond de dessication [The Massinian Durance Canyon (Provence, France): palaeogeographic evidence for a desiccated deep basin]. Palaeogeography, Paleoclimatology, Palaeoecology, 29: 15-40.

Davis D. G., 1965 - Observations in Bida Cave Grand Canyon National Park. Unpub. Rept. in files of Grand Canyon National Park, 5 p.

Davis D. G., 1970 - Folia in Carlsbad Cavern. Unpub. Rept. in files of Carlsbad Caverns National Park, 2 p.

Davis D. G., 1973 - Miniature folia in Groaning Cave, Colorado. Caving in the Rockies, 15 (1): 1.

Davis D. G., 1982 - Virgin passage found in Cave of the Winds. Caving in the Rockies, 24 (5): 54-55

Davis D. G., 1984 - Mysteries in mud: ancient frost-crystal impressions and other curiosities in Cave of the Winds, Colorado. Rocky Mountain Caving, 1 (3): 26-29.

Davis D., 1997 - Folia in Hurricane Crawl Cave and Crystal Sequoia Cave. San Francisco Bay Chapter, 40 (5) http://www.caves.org/grotto/sfbc/news/ vol40/issue-40-5.html [consult. dec. 2007]

Davis D., 2000 - Extraordinary features of Lechuguilla Cave, Guadalupe Mountains, New Mexico. Journal of Cave and Karst Studies, 62 (2): 147-157
De Waele J. \& Forti P., 2006 - A new hypogean karst form: the oxidation vent. Zeitschrift für Geomorphologie, suppl. 147: $107-127$

Emerson D., 1952 - Labor day Nevada Cave trip, 1951. California Caver, IV (8): 3-5.

FerrerRicoV.,2004-GrandescuevasysimasdelMediterráneo. De Gibraltar a Catalunya Nord. Guía fotográfica. 344 p. + CD-Rom. Author ed. <cuevasmediterraneo.com>

Forti P. \& Utili F., 1984 - Le concrezioni della Grotta Giusti [The speleothems of the Giusti Cave]. Speleo, 7 (7): 17-25.

Frumkin A., 1997 - Liquid Crystal Cave, Israel. In: Hill C. \& Forti P. - Cave minerals of the world. Huntsville, National Speleological Society: 319-322.

Galdenzi S. \& Sarbu S. M., 2000 - Chemiosintesi e speleogenesi in un ecosistema ipogeo: $i$ rami sulfurei delle grotte di Frasassi (Italia centrale) [Chemiosynthesis and speleogenesis in a hypogean ecosystem: the sulfuric gallery in Frasassi Cave (Central Italy)]. Le Grotte d'Italia, 1: 3-18

Green D. J., 1991 - On the origin of the folia and rims. Salt Lake Grotto Technical Note, 88: 182-196.

Green D. J., 1997 - The origin of folia. Salt Lake Grotto Tech. Note, 96: 51-60 [abstract in Journal of Cave and Karst Studies, 59 (1): 60].

Hall L., 2008 - Cuban Caves Photo Page, El Jarrito - Bellamar Cave system, Matanzas province, Cuba. The Pittsburg Grotto, http://www.karst.org/pgrotto/cubapics.htm [consult. May 2008]

Halliday W. R., 1954a - Basic geology of Crystal Cave, Utah. Salt Lake Grotto Technical Note, 16: 13.

Halliday W. R., 1954b - Basic geology of Goshute Cave, Nevada. Salt Lake Grotto Technical Note, 12: 1 -4.

Halliday W. R., 1957 - The Snake Creek Caves, White Pine County, Nevada. Salt Lake Grotto Technical Note, 39: 1-4.

Hill C. A., 1982 - Mineralogy of Bida Cave, Grand Canyon National Park, Arizona. Cave Research Foundation, Annual Report, 15: 29-30.

Hill C. A., 1987 - Geology of Carlsbad Cavern and other caves in the Guadalupe Mountains. New Mexico Bureau of Mines and Mineral Resources Memoir, 117, $150 \mathrm{p}$.

Hill C. A. \& Forti P., 1997 - Folia. In: Hill C. A. \& Forti P. - Cave minerals of the world. Huntsville, National Speleological Society: 73-74

Hose L. D., 1992 - To Lechuguilla Depths... Rocky Mountain Caver, 9 (2): 15-18.

Hose L.D., Palmer A.N., Palmer M.V., Northup D.E., Boston P.J. \& DuChene H.R., 2000 - Microbiology and geochemistry in a hydrogen-sulphide-rich karst environment. Chemical Geology, 169: 399-423.

Jennings J. N., 1982 - Karst of northeastern Queensland reconsidered. Tower Karst: Chillagoe Caving Club Occasional Paper, 4: 13-52.

Klimchouk A., 2007 - Hypogene speleogenesis. Hydrogeological and morphogenetic perspective. NCKRI Special Paper Series, 1, 77 p.

Kolesar P. T. \& Riggs A. C., 2004 - Influence of depositional environment on Devil's Hole calcite morphology and petrology. In: Sasowsky I.D. \& Mylroie J. (Eds.), Studies of Cave Sediments: Physical and Chemical Records of Paleoclimate. New York, Kluwer/Plenum Academic Press: 227-241 
Luiszer F. G., 1997 - Genesis of Cave of the Winds, Manitou Springs, Colorado. PhD Thesis, University of Colorado, $137 \mathrm{p}$.

Maltsev V.A., 1997 - Cupp-Countunn Cave, Turkmenistan. In: Hill C. \& Forti P. (Eds.) - Cave minerals of the world. Huntsville, National Speleological Society: 323-328

Maltsev V.A, 1999. Stalactites with "internal" and "external" feeding. Proceedings of the University of Bristol Spelaeological Society, 21 (2), 149-158

Maltsev V.A. \& Self C.A., 1993. Cupp-Coutunn cave system, Turkmenia, Central Asia. Proceedings of the University of Bristol Spelaeological Society, 19 (2), 117-149

Maucha L., 1993 - A Vass Imre-barlang természetvédelmi célu allapotfelvétel. Unpubl. Rept. to National Authority for Nature Conservation (Hungary), $22 \mathrm{p}$.

McLean J. S., 1965 - Folia found in Agua Caliente. Arizona Caver, 2 (6): 125.
Nuñez Jiménéz A., 1975 - Nivelitas nuevas formaciones espeleologicas ["Nivelitas", new cave formations]. Simp. 35" Aniv. Soc. Espeleol. Cuba, Resumenes, Isla de Pinos: 96.

Piccini L., 2000 - Il carsismo di origine idrotermale del Colle di Monsummano (Pistoia - Toscana) [The hydrothermal-origin karst from the Monsummano Hills (Pistoia - Tuscany]. Le Grotte d'Italia, 1: 33-43

Szabó Z., 2005 - Morphological and hydrological relationship of the Tapolca lake cave. Genesis and formation of hydrothermal Caves. International Conference, Budapest 2004, Papers: 100-105. Hungarian Speleological Society, Budapest.

Takacsné Bolner K., 1993 - Rare types of carbonate speleothems. Karszt és Barlang, 1-2: 29-36

Takácsné Bolner K., 2005 - Rare speleothems found in Pálvölgy cave. Genesis and formation of hydrothermal Caves. International Conference, Budapest 2004, Papers: 118124. Hungarian Speleological Society, Budapest. 